\title{
MOBILISASI DINI PADA PASIEN KRITIS DI INTENSIVE CARE UNIT (ICU): CASE STUDY
}

\author{
Bagus Ananta Tanujiarso1), Dilla Fitri Ayu Lestari²) \\ Program Studi S-1 Keperawatan STIKES Telogorejo Semarang1), \\ Semarang Medical Center (SMC) RS Telogorejo2)
}

\begin{abstract}
ABSTRAK
Pasien dengan ventilasi mekanik memerlukan perhatian khusus mengingat banyaknya penggunaan ventilasi mekanik di ICU seluruh dunia dan resiko Intensive Care Unit Acquired Weakness (ICU-AW). Penerapan mobilisasi dini sering kali mengalami hambatan, seperti adanya nyeri hebat, kelelahan, penurunan kesadaran, oversedasi, atau terpasang alat medis yang invasif. Penelitian ini bertujuan untuk mengetahui gambaran kemampuan pasien kritis dalam melakukan mobilisasi dini di ICU. Penelitian ini merupakan penelitian kualitatif dengan rancangan studi kasus. Pertisipan yang digunakan sebanyak 6 kasus pasien ICU yang dianalisis menggunakan metode five right clinical reasoning. Hasil analisis didapatkan 3 konsep utama yakni (1) kemampuan pasien kritis melakukan mobilisasi dini, (2) aktivitas mobilisasi yang dapat dilakukan pada pasien dengan kondisi kritis, dan (3) respon fisiologis pada pasien yang dilakukan mobilisasi dini. Terdapat beberapa aktivitas mobilisasi dini yang dapat dilakukan pasien kritis di ICU, seperti head up, memposisikan lateral, ROM, dan berkolaborasi dengan ahli fisioterapi. Perawatan yang berkesinambungan dan kerjasama tim kesehatan sangat dibutuhkan dalam proses mobilisasi pasien sakit kritis agar dapat memberikan perawatan yang lebih baik sehingga dapat meningkatkan kepuasan dan kualitas hidup pasien.
\end{abstract}

Kata kunci: Mobilisasi Dini; Pasien Kritis; Intensive Care Unit

\begin{abstract}
Patients with mechanical ventilation need special attention given the large number of mechanical ventilation uses in ICUs worldwide and the risk of the Intensive Care Unit Acquired Weakness (ICU-AW). The application of early mobilization often experiences obstacles, such as severe pain, fatigue, loss of consciousness, oversedation, or invasive medical devices. This study aims to describe the ability of critically ill patients in early mobilization at the ICU. This research is a qualitative research with a case study design. Participants used were 6 cases of ICU patients who were analyzed using the five right clinical reasoning method. The analysis results obtained 3 main concepts namely (1) the ability of critical patients to mobilize early, (2) mobilization activities that can be carried out in patients with critical conditions, and (3) physiological responses in patients who do early mobilization. There are several early mobilization activities that can be done by critically ill patients at the ICU, such as head ups, lateral positioning, ROM and collaboration with physiotherapists. Continuous care and collaboration of the health team is needed in the process of mobilizing critically ill patients in order to provide better care so as to increase patient satisfaction and quality of life.
\end{abstract}

Keywords: Early Mobilization, Critically Ill; Intensive Care Unit

Alamat korespondensi: Jl. Arteri Yos Sudarso/Jl. Puri Anjasmoro - Semarang (STIKES Telogorejo) Email: bagus@stikestelogorejo.ac.id 


\section{PENDAHULUAN}

Intensive care adalah salah satu layanan keperawatan untuk pasien dengan penyakit akut atau kronis dalam situasi darurat, kritis yang memerlukan monitoring fungsi vital, lebih khusus terapi intensif dan tindakan segera yang tidak dapat diberikan di ruang perawatan umum (Linda, Kathleen, \& Mary, 2010). Pasien kiritis yang ada di intensive care unit (ICU) umumnya mengalami bed rest dan memerlukan alat bantu nafas yakni ventilator mekanik. Pasien dengan ventilasi mekanik memerlukan perhatian khusus mengingat banyaknya penggunaan ventilasi mekanik di ICU seluruh dunia dan resiko terjadinya Intensive Care Unit Acquired Weakness (ICU-AW). ICU-AW menggambarkan pengecilan otot yang berhubungan dengan mortalitas tinggi, kondisi pasien yang buruk, serta keterlambatan proses penyapihan (Schaller et al., 2016). ICU-AW berpotensi diperburuk oleh periode bed rest yang lama karena sedasi dan imobilidsasi. Saat ini, intervensi mobilisasi dini yang disampaikan dalam pengaturan ICU yang bisa diterima sebagai intervensi terapeutik yang berpotensi dapat mencegah gangguan fungsional dan ICU-AW (L. Zhang et al., 2019). Namun, kapan waktu dimulainya mobilisasi dini masih menjadi perdebatan.

Mobilisasi dini telah diusulkan sebagai intervensi yang menjanjikan untuk menetralkan ICU-AW karena mampu mengurangi kelemahan otot terkait penyakit kritis (Pinheiro \& Christofoletti, 2012). Selain itu, aktivitas latihan secara dini memiliki potensi untuk mengurangi lenght of stay (LOS) di rumah sakit dan meningkatkan fungsi respirasi pada pasien dengan gagal napas akut (Verceles et al., 2018). Mobilisasi dini di ICU memberikan efek positif dan aman pada pasien dengan ventilator mekanik karena memberikan manfaat yang signifikan dari pengurangan durasi penggunaan ventilator mekanik serta LOS di ICU (G. Zhang, Zhang, Cui, Hong, \& Zhang, 2018).

Mobilisasi dini merupakan prosedur yang diberikan pada spektrum penyakit yang sangat luas antara lain kasus-kasus neurologis, kardiovaskular, muskuloskeletal, metabolik, trauma, dan sebagainya (Kress \& Hall, 2014). Tindakan mobilisasi dikerjakan di seluruh ruang perawatan mulai dari perawatan intensif hingga perawatan biasa. Mobilisasi dini sangat penting sehingga banyak penelitian dilakukan untuk membuktikan dampak dari mobilisasi dini, khususnya dalam upaya memperpendek masa perawatan (Rawal, Yadav, \& Kumar, 2017).

Kemampuan bergerak adalah kebutuhan penting manusia. Bergerak menyebabkan tubuh berada dalam reaksi anabolik yang tujuan akhirnya adalah regenerasi sel. Umumnya aktivitas fisik yang tinggi diikuti daya regenerasi yang baik, sehingga tubuh dapat berfungsi secara maksimal. Kondisi tirah baring lama menyebabkan tubuh mengalami penurunan berbagai fungsi tubuh secara sistematis, yang disebut dengan sindroma dekondisi (Hashem, Nelliot, \& Needham, 2016; Hunter, Johnson, \& Coustasse, 2014; Phelan, Lin, Mitchell, \& Chaboyer, 2018). Mulai 24-48 jam pertama tubuh akan secara perlahan melakukan adaptasi metabolik dan menurunkan aktivitas berbagai fungsi organ mulai dari sistem kardiorespirasi yang dimulai pada hari-hari pertama imobilisasi, sampai penghancuran protein otot dalam 2-3 minggu pertama, hingga berkurangnya massa tulang setelah beberapa bulan. Keseluruhan proses ini merupakan reaksi katabolik (Wunsch, Angus, Harrison, Linde-Zwirble, \& Rowan, 2011). Tidak mudah untuk mengembalikan proses katabolik ini menuju proses anabolik.

Sampai dengan saat ini, belum ada penjelasan mengenai waktu yang definitif mengenai kapan sebaiknya mobilisasi dini dimulai, apakah kurang dari 24 jam, dalam 24-48 jam, atau satu minggu (Pakasi, 2017). Setiap penyakit memiliki kompleksitas dan masalahnya masing-masing. Perawat harus dapat menentukan batasan-batasan yang aman secara fisiologis sebelum memulai mobilisasi. Sebagai contoh, potensi mobilisasi pada seorang penderita stroke akan berbeda dengan penderita gagal jantung, apalagi dibandingkan dengan pasien fraktur tungkai, atau pasien dengan penyakit paru obstruktif. Untuk itu pemahaman mengenai perjalanan berbagai kondisi pasien sangat penting sebelum proses mobilisasi dini dimulai. Penelitian ini bertujuan untuk mengetahui gambaran kemampuan pasien kritis dalam melakukan mobilisasi dini di ICU. 


\section{METODE PENELITIAN}

Penelitian ini merupakan penelitian kualitatif dengan rancangan studi kasus. Studi kasus termasuk dalam penelitian analisis deskriptif, yaitu penelitian yang dilakukan terfokus pada suatu kasus tertentu untuk diamati dan dianalisis secara cermat. Pada studi kasus, perlu dilakukan analisis secara tajam terhadap berbagai factor yang terkait dengan kasus tersebut sehingga akhirnya akan diperoleh kesimpulan yang akurat. Pengambilan data pada penelitian ini dilakukan pada tanggal 26 Agustus - 4 Oktober 2019 di ICU RSUD Tugurejo Semarang. Pertisipan yang digunakan untuk melaksanakan mobilisasi dini adalah 6 pasien dengan kriteria pasien dewasa ( $>18$ tahun) dan dirawat di ICU, tidak ada tanda-tanda peningkatan tekanan intracranial, dan kondisi hemodinamik stabil (tekanan darah, heart rate, respiration rate, dan suhu tubuh). Data yang diperoleh kemudian dianalisis menggunakan metode five right clinical reasoning.

\section{HASIL DAN PEMBAHASAN}

\section{Kasus 1}

Pasien Ny. S (52 tahun) Pasien tampak sesak napas, RR: 24 kali/menit, Akral hangat, pulsasi nadi teraba cukup. TD: 114/74 mmHg, HR: $101 \mathrm{kali} /$ menit, Suhu: $36^{\circ} \mathrm{C}, \mathrm{SaO}_{2}$ : 97\% dengan O2 nasal kanul 4 liter/menit, GCS $\mathrm{E}_{3} \mathrm{M}_{6} \mathrm{~V}_{2}$. Pasien mengalami kelemahan ekstremitas kiri. Terpasang NGT, DC, Infus perifer di tangan kanan. ADL dibantu oleh perawat. Pada pengkajian pola fungsional Gordon didapatkan data bahwa di rumah sakit, pasien mengalami gangguan pada pola aktivitas dan latihannya. Pasien mengalami kelemahan otot, sehingga tidak mampu beraktivitas secara optimal. Selain itu pasien juga mengalami penurunan kesadaran sehingga koordinasi tubuh untuk melakukan aktivitas juga terganggu. Data Penunjang pasien adalah dari hasil CT Scan kepala ditemukan adanya infark pada corona radiate kiri. Tak tampak gambaran intracerebral haemorrage, hasil Rontgen Thorax: Bronchopneumonia, cardiomegaly, hasil laboratorium: Hemoglobin: 11,8 g/dL, Leukosit: 13,7 103/ $\mu$ l, Ureum: $149 \mathrm{mg} / \mathrm{dL}$, Creatinin: 2,9 mg/dL, Cholestrol total: $193 \mathrm{mg} / \mathrm{dL}$, Trigliserid: 140 mg/dL, HDL: 37 mg/dL, LDL: 127 mg/dL, Asam urat: 6,1 mg/dL.

\section{Kasus 2}

Pasien Ny. S (52 tahun) Pada pengkajian didapatkan data bahwa pasien terpasang ETT sambung VM mode PSIMV. Ronkhi $(+/+)$. Leher tampak bengkak, Teraba masa pada thyroid sebelah kiri. Tak tampak otot bantu pernapasan. RR: 20 x/menit, SaO2: 97\%, TD: 112/84 mmHg, HR: $82 \mathrm{x} /$ menit, suhu: $36^{\circ} \mathrm{C}$. Akral hangat, pulsasi nadi teraba cukup, CRT 2 detik. Urine output $\pm 1600 \mathrm{ml} / 24$ jam. Pasien sadar. $\mathrm{E}_{4} \mathrm{M}_{6} \mathrm{~V}_{\text {ETT }}$. Terpasang NGT, DC, Infus perifer di tangan kanan. ADL dibantu oleh perawat. Berdasarkan pola pengkajian Gordon didapatkan data pasien tidak dapat melakukan aktivitas sehari hari dikarenakan menggunakan berbagai peralatan invasif. Pasien mengatakan tidak nyaman dengan berbagai peralatan yang terpasang. Pasien mengatakan nyeri. Hasil pemeriksaan CPOT 4. Pasien tidak mengguanakan terapi farmakologi untuk mengurangi nyeri. Hasil Ro Cervical: plegmon mediastinis. Hasil Ro Thorax: Cardiomegaly (LV,LA), edema pulmonum, efusi pleura kanan. Hasil Patologi Anatomi drain pleura: Reactive mesothelial cells, efusi pleura massif dd TB dd keganasan. Hasil Laboratorium: Hemoglobin: 11,6 g/dL, Leukosit: 12,8 103/ $\mu \mathrm{l}$, Trombosit: $42510^{3} / \mu \mathrm{l}$, Ureum: $30 \mathrm{mg} / \mathrm{dL}$, Creatinin: 0,37 mg/dL, Calcium: 7,8 mg/dL, Natrium: 142,5 mEq/L, Kalium: 4,25 mEq/L, pH:7,36, pCO $2: 37,2$ mmHg, pO $2: 79$ mmHg, $\mathrm{HCO}_{3}: 21$ $\mathrm{mmol} / \mathrm{L}, \mathrm{BE}:-4 \mathrm{mmol} / \mathrm{L}$.

\section{Kasus 3}

Pasien Ny. S (64 tahun) Berdasarkan hasil pengkajian didapatkan data pasien terpasang ETT sambung VM mode PSIMV. Sekret (+) warna putih kental. Reflek batuk (+) batuk tidak efektif. RR 32 x/menit, TD: 130/70 mmHg, HR: 96 x/menit, suhu 37,60 C, SpO2 97\%, akral hangat, pulsasi nadi teraba cukup. GCS $\mathrm{E}_{1} \mathrm{M}_{4} \mathrm{~V}_{\mathrm{ETT}}$. Terpasang, NGT, DC, Infus perifer di tangan kanan. ADL dibantu oleh perawat. Berdasarkan pola fungsional Gordon didapatkan data bahwa di rumah sakit, pasien mengalami gangguan pada pola aktivitas dan latihannya. Pasien mengalami kelemahan otot, sehingga tidak mampu beraktivitas secara optimal. Selain itu pasien juga mengalami penurunan 
kesadaran sehingga koordinasi tubuh untuk melakukan aktivitas juga terganggu. Data penunjang hasil laboratorium: albumin: 2,8 g/dL, GDS: $220 \mathrm{mg} / \mathrm{dL}$, Clorida: $113 \mathrm{mEq} / \mathrm{L}$, Kalium: 6,6 mEq/L, Calsium: 7,22 mg/dl, pH: 7,36, $\mathrm{pCO}_{2}: 42 \mathrm{mmHg}$, $\mathrm{pO}_{2}: 118 \mathrm{mmHg}, \mathrm{HCO}_{3}: 238 \mathrm{mmol} / \mathrm{L}, \mathrm{BE}:-2$ mmol/L. Hasil Rontgen Thorax: Cardiomegaly (LV), efusi pleura kiri (perbaikan minimal). Hasil CT scan kepala tanpa kontras infark luas pada sub cortisol fronto-temporo-parietal kanan, disertai tanda peningkatan TIK.

\section{Kasus 4}

Pasien Ny. S (28 tahun) Berdasarkan hasil pengkajian didapatkan bahwa pasien terpasang ETT sambung VM mode PSIMV. Sekret $(+)$ produksi sedikit warna putih encer. Reflek batuk kuat. Respirasi: 20-22 x/menit. Napas spontan adekuat. Tidak ada otot bantu napas. Tekanan Darah Sistolik: 100-125 mmHg. Diastolik: 55-70 mmHg. MAP: 70-88,3 mmHg. HR: 75-89 x/menit. Suhu: 36,50 C. Pasien composmentis. GCS $\mathrm{E}_{4} \mathrm{M}_{6} \mathrm{~V}_{\text {ETT. }}$ Terpasang NGT, DC, Infus perifer di tangan kanan. ADL dibantu oleh perawat. Berdasarkan pola fungsional gordon didapatkan data pasien tidak dapat melakukan aktivitas sehari hari dikarenakan menggunakan berbagai peralatan invasif. Pasien mengatakan tidak nyaman dengan berbagai peralatan yang terpasang. Pasien mengatakan nyeri. Hasil pemeriksaan CPOT: skor 3. Pasien tidak mengguanakan terapi farmakologi untuk mengurangi nyeri. Data penunjang hasil laboratorium. Hemoglobin: 8,8 g/dL. Hematokrit: 25,20\%.

Kasus 5

Pasien Ny. K (58 tahun) Terpasang ETT sambung VM mode PSIMV. Sekret $(+)$ produksi sedikit warna putih encer. Reflek batuk kuat. Respirasi: 20-22 x/menit. Napas spontan adekuat. Tidak ada otot bantu napas. Tekanan Darah Sistolik: 100-125 mmHg. Diastolik: 55-70 mmHg. MAP: 70- 88,3 mmHg. Herat Rate: 75-89 x/menit. Suhu: 36,50 C. Pasien composmentis. GCS E 4 M6V EтT. Berdasarkan pola fungsional Gordon didapatkan data bahwa pasien tidak dapat melakukan aktivitas sehari hari dikarenakan menggunakan berbagai peralatan invasif. Pasien mengatakan tidak nyaman dengan berbagai peralatan yang terpasang. Pasien mengatakan nyeri. Hasil pemeriksaan CPOT: skor 3. Pasien tidak mengguanakan terapi farmakologi untuk mengurangi nyeri. Data penunjang hasil laboratorium: Albumin: 3,0 g/dL, GDS: $524 \mathrm{mg} / \mathrm{dL}$, Chlorida: 113 $\mathrm{mEq} / \mathrm{l}$, Kalium: 6,6 mEq/L, Calsium: 8,2 mg/dL, $\mathrm{pH}: 7,36, \mathrm{pCO}_{2}: 42 \mathrm{mmHg}, \mathrm{pO}_{2}: 118 \mathrm{mmHg}$, $\mathrm{HCO}_{3}: 238 \mathrm{mmol} / \mathrm{L}, \mathrm{BE}:-2 \mathrm{mmol} / \mathrm{L}$.

\section{Kasus 6}

Pasien mengatakan sesak napas. Ronkhi $(+/+)$. Napas spontan $(+)$ adekuat dengan $\mathrm{O}_{2}$ Mask Non Rebreathing 10 liter/menit. Otot bantu napas (+). Ekspansi dada (+). TD: 130/70 mmHg. HR: 96 $\mathrm{x} /$ menit. Suhu 37,60 C. $\mathrm{SpO}_{2} 97 \%$. Akral hangat, pulsasi nadi teraba cukup. Pasien composmentis. GCS E4M6V4 Terpasang, NGT, DC, Infus perifer di tangan kanan. ADL dibantu oleh perawat Pasien tidak dapat melakukan aktivitas sehari hari dikarenakan menggunakan berbagai peralatan invasif. Pasien mengatakan tidak nyaman dengan berbagai peralatan yang terpasang. Pasien mengatakan nyeri. Hasil pemeriksaan CPOT: skor 3. Pasien tidak mengguanakan terapi farmakologi untuk mengurangi nyeri. Hasil Laboratorium Hemoglobin: 11,9 g/dL, Leukosit: 11,67

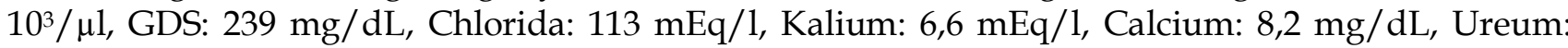
$86,0 \mathrm{mg} / \mathrm{dL}$, Creatinin: 5,85 mg/dL, hasil perekaman ECG menunjukkan: ST elevasi di AVR, ST depresi di V6, dan Rontgen Thorax menunjukkan: Cardiomegaly, dan bronchopneumonia.

\section{Pembahasan}

Pasien yang berada di ruang ICU mengalami berbagai macam kondisi kritis. Berdasarkan hasil studi kasus yang dianalisa menggunakan five right clinical reasoning, didapatkan beberapa tema, yaitu kemampuan pasien kritis melakukan mobilisasi dini, aktivitas mobilisasi dini yang dapat dilakukan pada pasien dengan kondisi kritis, serta respon fisiologis pada pasien yang dilakukan pasca perawatan di icu.

Tema 1: kemampuan pasien kritis melakukan mobilisasi dini

Dari hasil pengkajian didapatkan suatu kumpulan gejala berupa kelemahan anggota gerak kanan yang sifatnya mendadak. Pasien juga tidak dapat diajak berkomunikasi karena terjadinya penurunan kesadaran dengan onset akut. Pada penderita didapatkan deficit neurologis yang terjadi 
secara progresif berupa kelemahan motoric yang terjadi akibat suatu proses destruksi. Kesadaran ditentukan oleh kondisi pusat kesadaran yang berada di kedua hemisfer serebri dan Ascending Reticular Activating System (ARAS) yang terdapat di batang otak (Yeo, Chang, \& Jang, 2013). ARAS merupakan suatu rangkaian yang kaudal berasal dari medulla spinalis menuju rostral yaitu diansefalon melalui brain stem, sehingga kelainan yang mengenai lintasan ARAS tersebut akan menimbulkan penurunan derajat kesadaran (Yeo et al., 2013).

Pada kasus yang dipelajari, didapatkan data bahwa beberapa pasien terpasang ETT. Pasien dengan kasus tersebut membutuhkan mobilisasi dini untuk mencegah beberapa komplikasi pada pemasangan ETT yang tersambung dengan ventilasi mekanik. Pemasangan ETT menghambat mekanisme batuk alami yang merupakan mekanisme pertahanan alami tubuh terhadap infeksi pernapasan yang sering muncul pada pasien dengan ventilasi mekanik. Adanya ETT akan mencegah mukosiliar dalam pembersihan secret sehingga secret akan menumpuk di atas cuff ETT dan akhirnya dapat menyebabkan mikroaspirasi dan. Ketika mikroorganisme masuk ke dalam paru, mekanisme pertahanan tidak mampu membunuh organisme tersebut pneumonia (Ismaeil, Alfunaysan, Alotaibi, Alkadi, \& Othman, 2017). Pasien dengan tekanan intra kranial (TIK) meningkat tanpa diikuti dengan peningkatan tekanan darah boleh dilakukan mobilisasi karena terdapat fase kompensasi pada pasien yang mengalami peningkatan TIK. Fase 1 terjadi pada 48 jam pertama, fase kedua terjadi pada 2-14 hari, fase ke 3 terjadi pada minggu kedua. Setelah itu pasien mampu beradaptasi dan TIK kembali normal (Da Conceição, Gonzáles, De Figueiredo, Rocha Vieira, \& Bündchen, 2017).

Tema 2: aktivitas mobilisasi dini yang dapat dilakukan pada pasien dengan kondisi kritis

Aktivitas mobilisasi yang dapat dilakukan pada pasien kritis ditentukan dengan menggunakan alogaritme, sehingga level mobilisasi dapat menyesuaikan. Mobilisasi harus dilakukan bertahap sesuai tingkat kebutuhan dan toleransi pasien. Terdapat beberapa batasan dalam mobilisasi yang dijelaskan dalam penelusuran systematic review. Pasien dengan kondisi kritis dapat dilakukan mobilisasi dini dengan karakteristik seperti stabilitas kardiovaskular, respiratori, neurologi, orthopedic, dan stabilitas lainnya (Da Conceição et al., 2017). Stabilitas kardiovaskular meliputi: frekuensi nadi $>40 \mathrm{x} /$ menit dan $<130 \mathrm{x} /$ menit, Tekanan darah sistolik $>90 \mathrm{mmHg}$ dan $<180 \mathrm{mmHg}$, Mean atrial pressure (MAP) $>60 \mathrm{mmHg}$ dan $<110 \mathrm{mmHg}$, tidak ada peningkatan obat vasopressor dalam 2 jam terakhir, tidak ada iskemik miokard, tidak ada aritmia, tidak ada kateter arteri femoral, serta tidak ada pemberian antiaritmia yang berulang (rutin) (Da Conceição et al., 2017). Stabilitas respiratori meliputi frekuensi nafas $>5 \mathrm{x} /$ menit dan $<35 \mathrm{x} /$ menit, $\mathrm{SaO}_{2} \geq 90 \%, \mathrm{f}_{\mathrm{i}} \mathrm{O}_{2}$ $<0,6$, PEEP $<10 \mathrm{cmH}_{2} \mathrm{O}$, serta jalan napas terlindungi. Stabilitas neurologi meliputi tidak ada tandatanda peningkatan TIK, tidak dalam level kesadaran koma, tidak gelisah, dapat mengikuti perintah dengan baik, merespon dengan rangsangan verbal, serta tidak ada penyakit neurologi atau neuromuscular yang menghalangi aktivitas mobilisasi. Kestabilan ortopedi meliputi tidak ada fraktur yang tidak stabil dan tidak ada kontraindikasi ortopedi untuk mobilisasi. Ketidakstabilan lainnya meliputi tidak ada neuromuscular bloking agent, tidak ada pembukaan abdomen, tidak dalam perawatan paliatif, tidak ada DVT, suhu tubuh $<38,5^{\circ} \mathrm{C}$, tidak ada perdarahan gastrointestinal yang aktif, dan tidak ada perdarahan aktif (Da Conceição et al., 2017).

Terdapat beberapa variasi praktik dalam mobilisasi dini. Variasi praktik ada pada waktu pelaksanaan, aktivitas mobilisasi, protocol pelaksanaan, dan ekspektasi hasil. Waktu pelaksanaan mobilisasi dini dapat dimulai saat pasien berada dalam kondisi akut dengan memperhatikan stabilitas kondisi fisiologi dan psikologi. Mobilisasi dini dapat dilakukan 24 jam pertama setelah admisi atau antara 48-72 jam pertama pasien masuk ke ICU (Clarissa, Salisbury, Rodgers, \& Kean, 2019). Aktivitas yang dapat dilakukan beragam, mulai dari perubahan posisi, aktivitas yang melibatkan tulang panjang seperti range of motion (ROM), serta aktivitas lain diluar ROM (Clarissa et al., 2019). American Association of Critical Care Nurses (AACN) memperkenalkan intervensi mobilisasi progresif yang terdiri dari beberapa tahapan: Head of Bed (HOB), latihan Range of Motion (ROM) pasif dan aktif, terapi lanjutan rotasi lateral, posisi tengkurap, pergerakan melawan gravitasi, posisi duduk, posisi kaki menggantung, berdiri dan berjalan (Vollman, 2013). 
Mobilisasi dini dapat dilakukan oleh perawat secara mandiri ataupun dilakukan secara kolaborasi oleh pemberi asuhan (perawat, fisoterapi, okupasional terapi) (Clark, Lowman, Griffin, Matthews, \& Reiff, 2013). Perawat harus melakukan informed consent kepada keluarga sebelum melakukan mobilisasi dini. Jika keluarga menyetujui, maka keluarga juga dapat diajak untuk melakukan mobilisasi sederhana, sehingga family participation dan caring keluarga dapat meningkat. Mobilisasi dini dapat dilakukan dua kali sehari, sehari sekali, atau bahkan dapat dilakukan tiap dua jam sekali, misal pada saat pasien dilakukan alih baring (Frownfelter \& Dean, 2014). Hal yang diharapkan dari mobilisasi dini yaitu mencegah komplikasi akibat perawatan yang dilakukan, memperbaiki mobilitas pasien, dan meningkatkan penurunan nilai kewaspadaan.

Tema 3: respon fisiologis pada pasien yang dilakukan mobilisasi dini

Pasien Kritis menghabiskan waktu yang lama untuk masa rawat di rumah sakit. Perubahan besar terjadi pada sistem kardiovaskular saat bedrest (Petruccio, Monteiro, Liz, Oliveira, \& Carvalho, 2018). Posisi terlentang membuat $11 \%$ dari volume darah menghilang dari kaki, yang seharusnya banyak menuju dada. Dalam 3 hari pertama bedrest volume plasma akan berkurang $8 \%$ sampai $10 \%$. Kerugian menjadi $15 \%$ sampai $20 \%$ pada minggu keempat (Petruccio et al., 2018). Perubahan ini mengakibatkan peningkatan beban kerja jantung, peningkatan masa istirahat denyut jantung, dan perubahan stoke volume menyebabkan penurunan cardiac out put (COP). Secara teori tekanan darah dapat dipengaruhi oleh beberapa faktor yaitu COP, preload, dan resistensi perifer (Pathmanathan, Beaumont, \& Gratrix, 2015). COP merupakan jumlah darah yang dikeluarkan dari ventrikel kiri dalam satu menit. Preload merupakan tekanan saat pengisian atrium kanan selama diastolik yang menggambarkan volume dari aliran balik jantung (Wilcken, 2014).

Perubahan posisi mempunyai efek terhadap perubahan tekanan darah dan tekanan vena sentral (Lesmana, Ose, Zulfia, \& Tobing, 2019). Pada posisi head of bed menunjukkan aliran balik darah dari bagian inferior menuju ke atrium kanan cukup baik karena resistensi pembuluh darah dan tekanan atrium kanan tidak terlalu tinggi, sehingga volume darah yang masuk (venous return) ke atrium kanan cukup baik dan tekanan pengisian ventrikel kanan (preload) meningkat, yang dapat mengarah pada peningkatan stroke volume dan cardiac output (Bein et al., 2015). Perubahan posisi lateral atau miring mempengaruhi aliran balik darah yang menuju ke jantung dan berdampak pada hemodinamik. Pada pasien kritis lebih baik untuk diberikan mobilisasi dari pada pasien dibiarkan dalam posisi supine secara terus menerus. Karena dengan membiarkan pasien dalam keadaan imobilisasi akan memberi dampak yang buruk pada organ tubuh (Bein et al., 2015). Maka dari itu perawat perlu merencanakan kegiatan mobilisasi kepada pasien.

Mobilisasi adalah kegiatan fundamental keperawatan yang membutuhkan pengetahuan dan keterampilan untuk menerapkan secara efektif untuk pasien sakit kritis (Green, Marzano, Leditschke, Mitchell, \& Bissett, 2016). Mobilisasi dapat menghasilkan outcome yang baik bagi pasien seperti meningkatkan pertukaran gas, mengurangi angka VAP, mengurangi durasi penggunaan ventilator, dan meningkatkan kemampuan fungsional jangka panjang (Green et al., 2016). Ketidakstabilan hemodinamik merupakan salah satu tantangan untuk perawat dalam melakukan mobilisasi pada pasien kritis. Untuk menyeimbangkan antara risiko dan manfaat dari mobilisasi pada pasien kritis maka perawat harus menentukan jenis mobilisasi yang tepat, memperhatikan penyakit tertentu, mengkaji faktor risiko, menentukan waktu sesi mobilisasi, mengurangi kecepatan saat melakukan mobilisasi yang dapat mempengaruhi respon sistem kardiovaskular (Garzon-Serrano et al., 2011).

Pada pasien kritis konsekuensi terbesar dari bedrest atau imobilisasi adalah sistem pernafasan meliputi pengembangan kompresi atelectasis dari pembentukan edema dengan pasien posisi supine dan kelemahan fungsi paru, reflek batuk, dan drainase tidak bekerja dengan baik ketika pasien dalam posisi supine (Vollman, 2013). Hal ini akan berdampak pada oksigenasi karena kelemahan fungsi paru akibat imobilisasi. Saturasi oksigen merupakan salah satu indikator dari status oksigenasi. Saturasi oksigen adalah kemampuan haemoglobin mengikat oksigen. Faktorfaktor yang mempengaruhi saturasi oksigen yaitu jumlah oksigen yang masuk ke paru-paru (ventilasi), kecepatan difusi, dan kapasitas haemoglobin dalam membawa oksigen (Vollman, 2013). 
Diharapkan bahwa mobilisasi akan meningkatkan transportasi oksigen pasien, karena efek positif dari posisi tegak pada ventilasi alveolar dan perfusi.

\section{SIMPULAN}

Terdapat beberapa aktivitas yang dilakukan di ruang ICU, seperti head up, memposisikan lateral, ROM dan berkolaborasi dengan ahli fisioterapi. Namun demikian, menerapkan mobilisasi dini pada pasien di ICU sering kali mengalami hambatan. Kendala yang paling umum ditemukan adalah kondisi pasien yang tidak memungkinkan untuk mobilisasi, seperti adanya nyeri hebat, kelelahan, penurunan kesadaran, oversedasi, atau terpasang alat medis yang invasif. Melakukan mobilisasi dini juga sangat bergantung pada keterampilan petugas kesehatan yang ada di ICU, fisioterapis, dan ketersediaan alat yang mendukung mobilisasi di ICU.

\section{SARAN}

Kerjasama tim kesehatan diperlukan dalam proses mobilisasi pasien sakit kritis yang ada di ICU. Kesinambungan perawatan yang bersinergi dalam melakukan mobilisasi dini dapat menjadi program perawatan yang lebih baik, sehingga kepuasan dan kualitas hidup pasien dapat ditingkatkan.

\section{DAFTAR PUSTAKA}

Bein, T., Bischoff, M., Brückner, U., Gebhardt, K., Henzler, D., Hermes, C., ... Wrigge, H. (2015). S2eLeitlinie: Lagerungstherapie und Frühmobilisation zur Prophylaxe oder Therapie von pulmonalen Funktionsstörungen: Revision 2015: S2e-Leitlinie der Deutschen Gesellschaft für Anästhesiologie und Intensivmedizin (DGAI). Anaesthesist, 64(September), 1-26. https://doi.org/10.1007/s00101-015-0071-1

Clarissa, C., Salisbury, L., Rodgers, S., \& Kean, S. (2019). Early mobilisation in mechanically ventilated patients: A systematic integrative review of definitions and activities. Journal of Intensive Care, 7(1), 1-19. https:/ / doi.org/10.1186/s40560-018-0355-z

Clark, D. E., Lowman, J. D., Griffin, R. L., Matthews, H. M., \& Reiff, D. A. (2013). Effectiveness of an Early Mobilization Protocol in a Trauma and Burns Intensive Care Unit: A Retrospective Cohort Study. Physical Therapy, 93(2), 186-196. https://doi.org/10.2522/ptj.20110417

Da Conceição, T. M. A., Gonzáles, A. I., De Figueiredo, F. C. X. S., Rocha Vieira, D. S., \& Bündchen, D. C. (2017). Safety criteria to start early mobilization in intensive care units. Systematic review. Revista Brasileira de Terapia Intensiva, 29(4), 509-519. https://doi.org/10.5935/0103507X.20170076

Frownfelter, D., \& Dean, E. (2014). Cardiovascular and pulmonary physical therapy-E-Book: Evidence to practice (Fifth Edit; K. Falk, Ed.). St. Louis, Missouri: Elsevier Mosby.

Garzon-Serrano, J., Ryan, C., Waak, K., Hirschberg, R., Tully, S., Bittner, E. A., ... Eikermann, M. (2011). Early mobilization in critically ill patients: Patients' mobilization level depends on health care provider's profession. PM and R, 3(4), 307-313. https://doi.org/10.1016/j.pmrj.2010.12.022

Green, M., Marzano, V., Leditschke, I. A., Mitchell, I., \& Bissett, B. (2016). Mobilization of intensive care patients: A multidisciplinary practical guide for clinicians. Journal of Multidisciplinary Healthcare, 9, 247-256. https://doi.org/10.2147/JMDH.S99811

Hashem, M. D., Nelliot, A., \& Needham, D. M. (2016). Early mobilization and rehabilitation in the ICU: Moving back to the future. Respiratory Care, 61(7), 971-979. https://doi.org/10.4187/respcare.04741

Hunter, A., Johnson, L., \& Coustasse, A. (2014). Reduction of intensive care unit length of stay: The case of early mobilization. Health Care Manager, 33(2), 128-135.

https://doi.org/10.1097/HCM.0000000000000006

Ismaeil, T., Alfunaysan, L., Alotaibi, N., Alkadi, S., \& Othman, F. (2017). Repositioning of 
endotracheal tube and risk of ventilator-associated pneumonia among adult patients: A matched case-control study. Annals of Thoracic Meedicine, 13(3), 156-162. https://doi.org/10.4103/atm.ATM

Kress, J. P., \& Hall, J. B. (2014). ICU-acquired weakness and recovery from critical illness. New England Journal of Medicine, 370(17), 1626-1635. https:/ / doi.org/10.1056/NEJMra1209390

Lesmana, H., Ose, M. I., Zulfia, R., \& Tobing, K. I. S. (2019). The Effect of Changes in Postural Position Angle Degree on Central Venous Pressure Measurement. Indonesian Journal of Medicine, 4(3), 192-200. https:/ / doi.org/10.26911/theijmed.2019.04.03.01

Linda, D., Kathleen, M., \& Mary, E. (2010). Critical care nursing: Diagnosis and management (8th ed.). St Louis: Mosby.

Pakasi, R. (2017). Mobilisasi dini: kapan sebaiknya diberikan? Retrieved January 3, 2020, from perdosri.or.id website: https://perdosri.or.id/mobilisasi-dini-kapan-sebaiknya-diberikan/

Pathmanathan, N., Beaumont, N., \& Gratrix, A. (2015). Respiratory physiotherapy in the critical care unit. Continuing Education in Anaesthesia, Critical Care and Pain, 15(1), 20-25. https://doi.org/10.1093/bjaceaccp/mku005

Petruccio, L., Monteiro, C., Liz, M., Oliveira, C. De, \& Carvalho, G. D. A. (2018). Deleterious effects of prolonged bed rest on the body systems of the elderly - a review. 499-506.

Phelan, S., Lin, F., Mitchell, M., \& Chaboyer, W. (2018). Implementing early mobilisation in the intensive care unit: An integrative review. International Journal of Nursing Studies, 77(September 2017), 91-105. https://doi.org/10.1016/j.ijnurstu.2017.09.019

Pinheiro, A. R., \& Christofoletti, G. (2012). Motor physical therapy in hospitalized patients in an intensive care unit: A systematic review. Revista Brasileira de Terapia Intensiva, 24(2), 188-196. https:// doi.org/10.1590/S0103-507X2012000200016

Rawal, G., Yadav, S., \& Kumar, R. (2017). Post-intensive care syndrome: An overview. Journal of Translational Internal Medicine, 5(2), 90-92. https://doi.org/10.1515/jtim-2016-0016

Schaller, S. J., Anstey, M., Blobner, M., Edrich, T., Grabitz, S. D., Gradwohl-Matis, I., ... Eikermann, M. (2016). Early, goal-directed mobilisation in the surgical intensive care unit: a randomised controlled trial. The Lancet, 388(10052), 1377-1388. https:/ / doi.org/10.1016/S01406736(16)31637-3

Verceles, A. C., Wells, C. L., Sorkin, J. D., Terrin, M. L., Beans, J., Jenkins, T., ... Medicine, G. (2018). HHS Public Access. 204-210. https:// doi.org/10.1016/j.jcrc.2018.07.006.A

Vollman, K. M. (2013). Understanding critically ill patients hemodynamic response to mobilization: Using the evidence to make it safe and feasible. Critical Care Nursing Quarterly, 36(1), 17-27. https://doi.org/10.1097/CNQ.0b013e3182750767

Wilcken, D. E. L. (2014). Physiology of the normal heart. Medicine (United Kingdom), 42(8), 409-412. https://doi.org/10.1016/j.mpmed.2014.05.008

Wunsch, H., Angus, D. C., Harrison, D. A., Linde-Zwirble, W. T., \& Rowan, K. M. (2011). Comparison of medical admissions to intensive care units in the United States and United Kingdom. American Journal of Respiratory and Critical Care Medicine, 183(12), 1666-1673. https://doi.org/10.1164/rccm.201012-1961OC

Yeo, S. S., Chang, P. H., \& Jang, S. H. (2013). The ascending reticular activating system from pontine reticular formation to the thalamus in the human brain. Frontiers in Human Neuroscience, 7(JUL), 1-5. https://doi.org/10.3389/fnhum.2013.00416

Zhang, G., Zhang, K., Cui, W., Hong, Y., \& Zhang, Z. (2018). The effect of early mobilization for critical ill patients requiring mechanical ventilation: a systematic review and meta-analysis. Journal of Emergency and Critical Care Medicine, 2(Mv), 9-9. https://doi.org/10.21037/jeccm.2018.01.04

Zhang, L., Hu, W., Cai, Z., Liu, J., Wu, J., Deng, Y., ... Qin, Y. (2019). Early mobilization of critically ill patients in the intensive care unit: A systematic review and meta-analysis. PLoS ONE, 14(10), 1-16. https://doi.org/10.1371/journal.pone.0223185 